\title{
Sustainability benchmarking of European banks and financial service organizations
}

\section{Working Paper}

\section{Author(s):}

Weber, Olaf; Reiland, Rol; Weber, Bernhard

Publication date:

2002

Permanent link:

https://doi.org/10.3929/ethz-a-004478125

Rights / license:

In Copyright - Non-Commercial Use Permitted

Originally published in:

Working Paper / UNS 34 


\section{Working Paper}
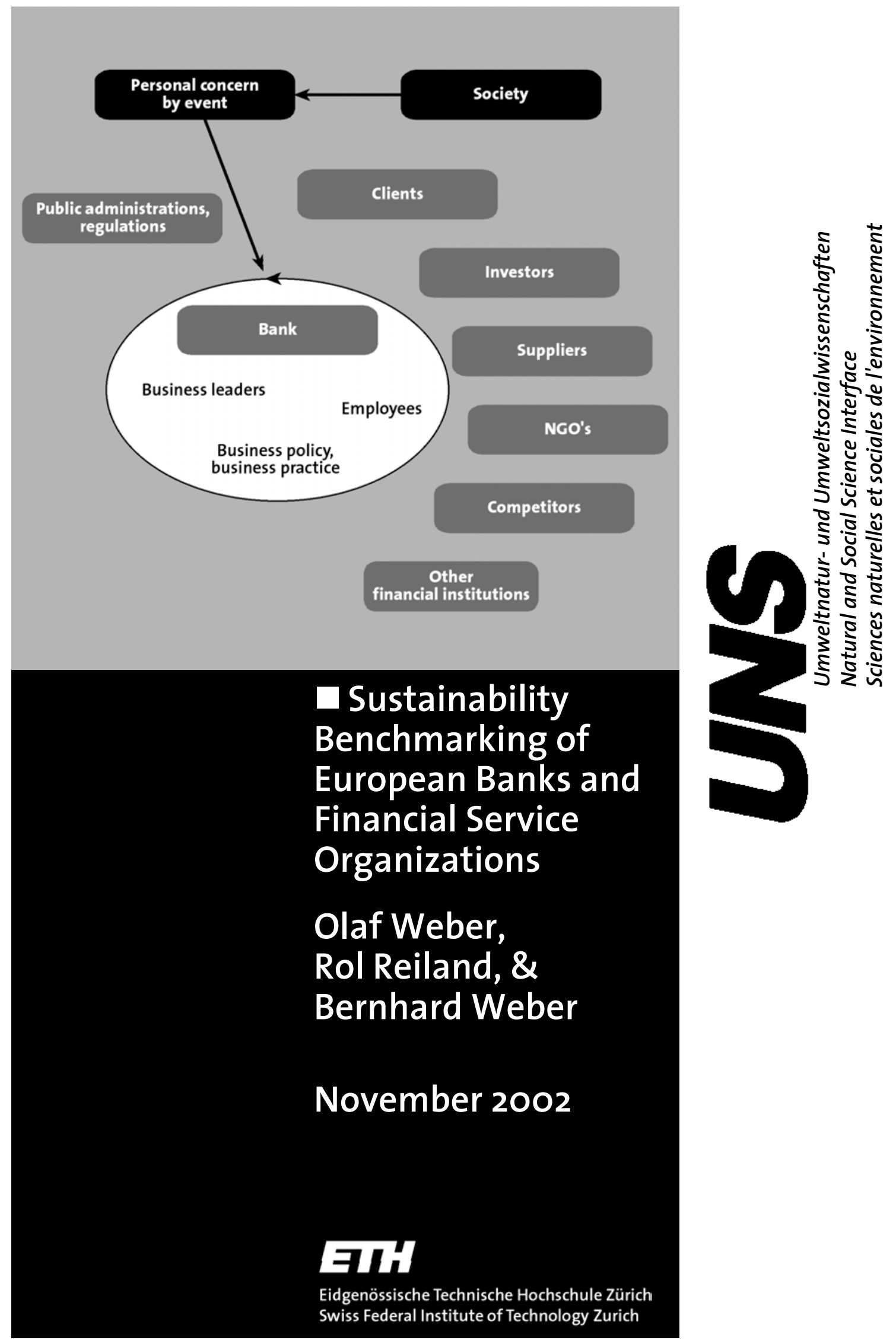

Eidgenössische Technische Hochschule Zürich Swiss Federal Institute of Technology Zurich 


\section{Natural and Social Science Interface (UNS)}

Publisher:

Prof. Dr. Roland W. Scholz

Umweltnatur- und

Umweltsozialwissenschaften (UNS)

ETH Zentrum HAD

Haldenbachstrasse 44

$\mathrm{CH}-8092$ Zürich

Tel. $\quad++41-1-6325892$

Fax ++41-1-63210 29

E-mail: scholz@uns.umnw.ethz.ch

Corresponding author:

Dr. Olaf Weber

Umweltnatur- und

Umweltsozialwissenschaften (UNS)

ETH Zentrum HAD

$\mathrm{CH}-8092$ Zürich

Tel. ++41-1-632 6444

Fax ++41-1-632 1029

E-mail:olaf.weber@uns.umnw.ethz.ch

Co-authors:

Rol Reiland

Umweltnatur- und

Umweltsozialwissenschaften (UNS)

ETH Zentrum HAD

$\mathrm{CH}-8092$ Zürich

Bernhard Weber

Umweltnatur- und

Umweltsozialwissenschaften (UNS)

ETH Zentrum HAD

$\mathrm{CH}-8092$ Zürich

\section{EIH}

Eidgenössische Technische Hochschule Zürich Swiss Federal Institute of Technology Zurich 


\section{Sustainability Benchmarking of European Banks and Financial Service Organizations}

Olaf Weber, Rol Reiland, \& Bernhard Weber

\section{Contents}

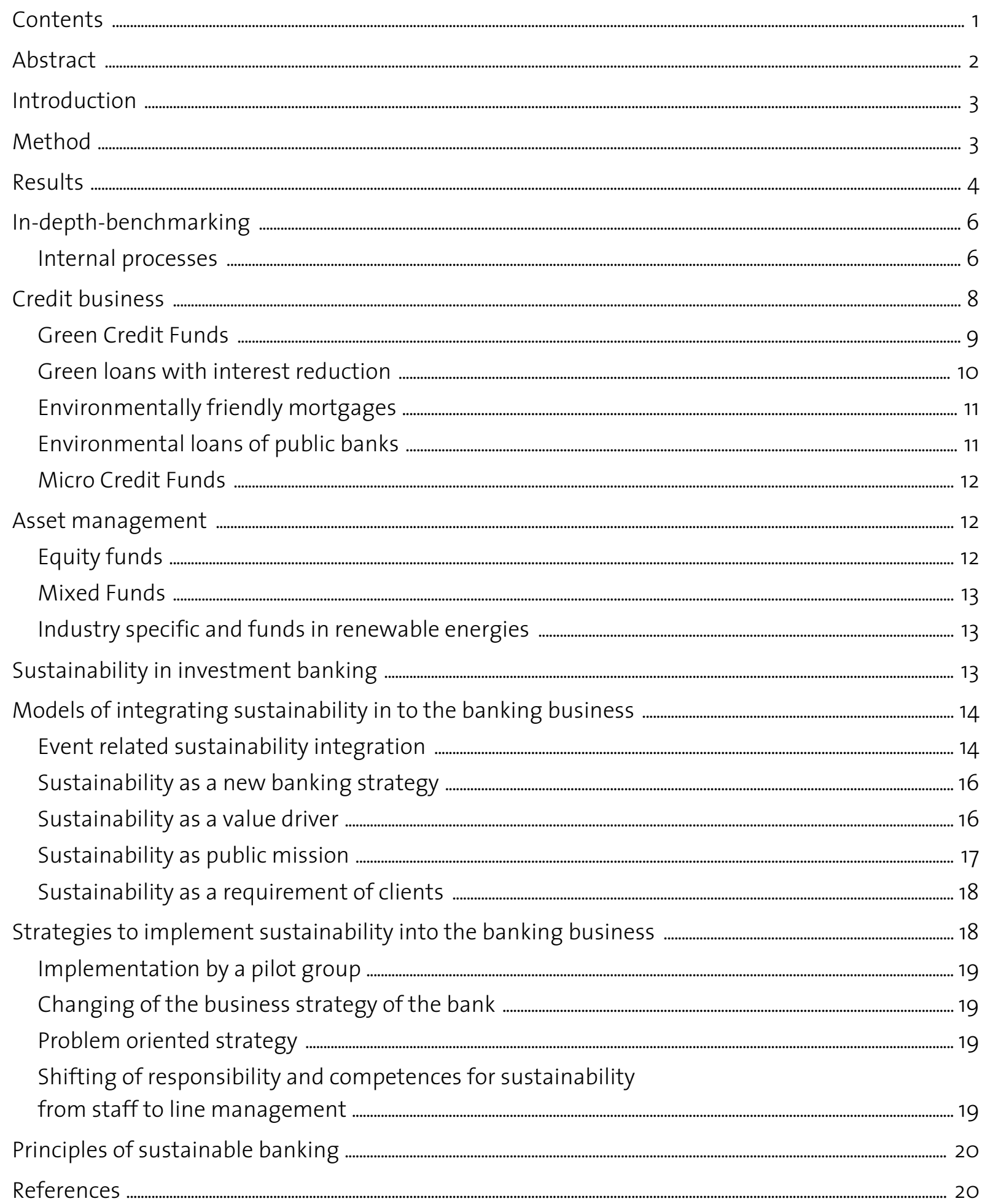




\section{Abstract}

In this paper we present a benchmarking of European banks and service organizations regarding the integration of sustainability in their policies, strategies, products, services and processes.

Using a multi level analysis starting with a screening from 127 organizations and ending with in depth interviews with eight organizations we could analyze both the state of the art and the best in class integration of sustainability.

We analyzed the business fields credit business, asset management, and investment banking. For every business field we present the leaders in sustainability integration.

In addition we found five models of successful integration of sustainability into the banking business as they are the event related sustainability integration, sustainability as a new banking strategy, sustainability as value driver, sustainability as public mission, and sustainability as a requirement of clients. Different banks can use those models to implement sustainability in their business.

As successful strategies to implement sustainability in banks and financial institutions we found the implementation by a pilot group, the change of the business strategy, the problem oriented strategy, and the shifting of responsibility and competences for sustainability from staff to line management.

Thus the principles of sustainable banking we could extract out of the study are first, the integration of sustainability into the core business of the bank, second, the integration of sustainability into the general business strategy, and third to deal with sustainability not as a soft factor, but as a measurable business result. 


\section{Introduction}

Since Schmidheinys and Zorraquins book Financing Change (1996) sustainability seems to play an important role in the financial services sector in both strategy and operative business (Jeucken, 2001). Since 1992 there exists even a UNEP Statement by Financial Institutions on the Environment \& Sustainable Development (UNEP, 1992).

In this statement the signatories recognize that they want to work cooperatively with government, business, and individuals toward common environmental goals. One important statement out of others is that the signatories encourage the financial services sector to develop products and services, which will promote environmental protection. This statement means that a development of products should not only positively impact the development of the bank itself, but sustainable development as well.

Based on this statement we conducted a benchmarking in the European Financial Services Sector. This benchmarking wanted to answer the following questions:

- In which European banks and financial services institutions exist strategies, processes, services, and products fostering sustainable development?

- How do those strategies, processes, services, and products look like?

-Why integrate banks and financial institutions such sustainable strategies, processes, services, and products into their business policy and their operational business?

In general we wanted to analyze how the integration of sustainability into policies, strategies, products, and services of banks and financial institutions has developed.

\section{Method}

We used a multilevel design (see Figure 1) to conduct this benchmarking.

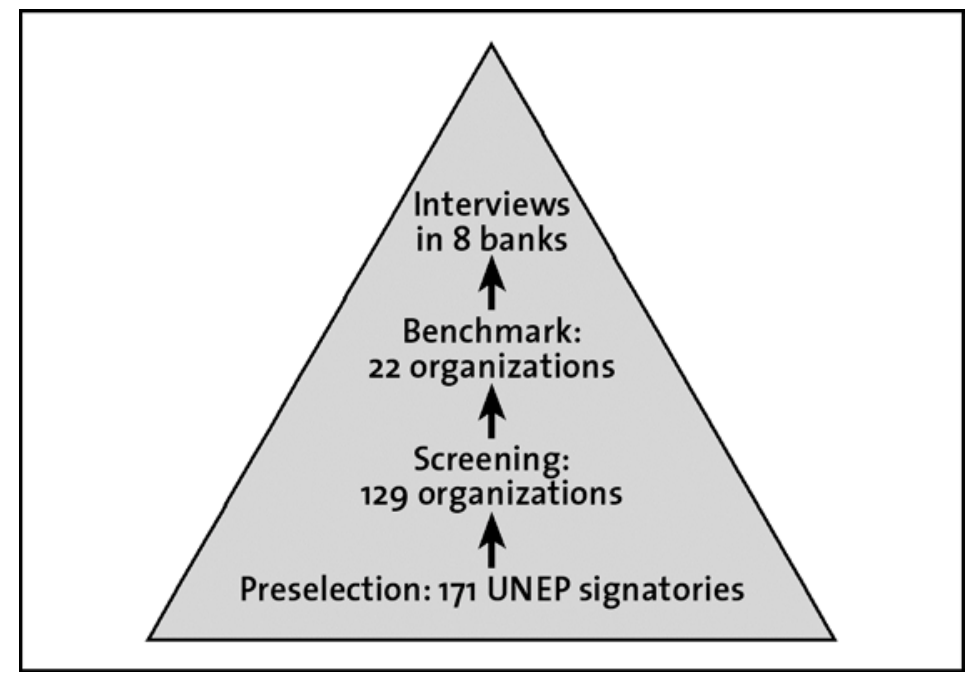

Figure 1: Multilevel Design 
We started with a preselection of the 171 UNEP signatories of the year 2001. Out of these 171 we extracted the 129 European organizations. By analyzing their business reports using a checklist we could find the 22 most "sustainable" organizations. These organizations can be accepted as the European sustainability leaders of the financial sector. Out of these leaders we interviewed representatives of organizations, which showed outstanding strategies, processes, services or products. The main goal of the interviews was to find out why these organizations integrated those outstanding strategies, processes, services or products into their business.

The checklist we used for the screening consisted of the parts management, reporting, sustainability management, and product sustainability. We used this checklist to analyze written reports and internet information of the banks.

To analyze the banks we used a sector specific benchmarking (Mertins, Siebert, \& Kempf, 1995). That means the sample consisted only of banks and companies of the financial sector. Insurances were excluded.

In every bank we analyzed the integration of sustainability in the following business units with the listed criteria of the cheklist:

- Operational sustainability: sustainability program, reporting, energy consumption, ratio renewable energy to total energy consumption, business related mobility, paper consumption, sustainability management, social criteria, stakeholder communication.

- Investment: Investment in sustainable projects, shares or funds as positive criteria and the rejection of investments in non-sustainable projects, shares or funds as negative criteria, existing of a sustainability advisory board, investment in sustainable pioneer companies.

- Credit: Credits for sustainable companies and projects like micro credits, social housing, eco-projects as positive criteria and exclusion of credits for non-sustainable companies and projects. Existing of a sustainability advisory board, registration of the environmental impact of the credits, environmental rating or scoring, connection between credit pricing and sustainability performance of the debtor, credits for sustainable startups, transparency of credit products and debtors.

For every business field we used a four-point scale to judge the products, services and processes. To avoid subjective evaluations always two persons evaluated the business. Afterwards we compared the evaluation and created a consented opinion.

\section{Results}

At the first step we could identify 21 banks and financial institutions, which integrate sustainability into their business strategy and practice. We grouped these banks into the groups alternative banks, cooperative banks, banks under public law, asset management and investment companies, national and international universal banks. In Table 1 we present those banks we could identify as the sustainability leader in the first step of the benchmark. 
Table 1: Sustainability leaders after the first benchmarking step

\begin{tabular}{|c|c|c|c|c|c|}
\hline Group & Name & Country & $\begin{array}{l}\text { Number of } \\
\text { Employees }\end{array}$ & $\begin{array}{c}\text { Balance } \\
\text { Sum in } \\
\text { Billion Euro }\end{array}$ & Description \\
\hline \multirow[t]{3}{*}{ Alternative Banks } & TRIODOS & $\begin{array}{l}\text { NL, B, } \\
\text { UK }\end{array}$ & 147 & 0.62 & $\begin{array}{l}\text { Founded } 1980 \text { with the goal to } \\
\text { finance sustainable projects } \\
\text { and ideas (www.triodos.com) }\end{array}$ \\
\hline & ASN & NL & & 1.0 & $\begin{array}{l}\text { Founded } 1960 \text { by labor } \\
\text { movement as ethical bank } \\
\text { (www.asnbank.nl) }\end{array}$ \\
\hline & UmweltBank & $\mathrm{D}$ & 90 & 0.22 & $\begin{array}{l}\text { Founded } 1997 \text { with the goal to } \\
\text { finance environmental friendly } \\
\text { projects and ideas } \\
\text { (www.umweltbank.de) }\end{array}$ \\
\hline \multirow[t]{2}{*}{ Cooperative Banks } & $\begin{array}{l}\text { Co-operative } \\
\text { Bank }\end{array}$ & UK & 4100 & 10.88 & www.co-operativebank.co.uk \\
\hline & $\begin{array}{l}\text { Rabobank } \\
\text { Group }\end{array}$ & NL & 49711 & 377 & $\begin{array}{l}\text { Transnational } \\
\text { (www.rabobank.com) }\end{array}$ \\
\hline \multirow{4}{*}{$\begin{array}{l}\text { Banks under public } \\
\text { law }\end{array}$} & ZKB & $\mathrm{CH}$ & 4071 & 53.07 & www.zkb.com \\
\hline & BOS & $\mathrm{PL}$ & 1500 & 0.94 & $\begin{array}{l}\text { Founded } 1991 \text { with the goal to } \\
\text { finance environmental projects } \\
\text { in Poland (www.bosbank.pl) }\end{array}$ \\
\hline & DtA & $\mathrm{D}$ & 800 & 53.4 & $\begin{array}{l}\text { Founded 1950, promotion of } \\
\text { start ups and environmental } \\
\text { protection (www.dta.de) }\end{array}$ \\
\hline & DEG & $\mathrm{D}$ & 291 & 1.73 & $\begin{array}{l}\text { Founded 1962, loans for foreign } \\
\text { investments } \\
\text { (www.deginvest.de) }\end{array}$ \\
\hline \multirow{4}{*}{$\begin{array}{l}\text { Asset management } \\
\text { and investment } \\
\text { companies, private } \\
\text { banks }\end{array}$} & SPG & $\mathrm{CH}$ & & 0.18 & $\begin{array}{l}\text { Investment trust connected } \\
\text { with SAM (www.sam- } \\
\text { group.com) }\end{array}$ \\
\hline & $\begin{array}{l}\text { Bank Sarasin } \\
\& \text { Cie. }\end{array}$ & $\mathrm{CH}$ & 710 & 3,56 & $\begin{array}{l}\text { Private Bank founded } 1841 \\
\text { (www.sarasin.com }\end{array}$ \\
\hline & SEB-Invest & $\mathrm{D}$ & & $7^{1}$ & $\begin{array}{l}\text { Belongs to SEB Bank (www.seb- } \\
\text { invest.de) }\end{array}$ \\
\hline & $\begin{array}{l}\text { Friends } \\
\text { Provident }\end{array}$ & UK & 90 & 60.73 & www.friendsprovident.co.uk \\
\hline \multirow[t]{7}{*}{ Universal Banks } & Credit Suisse & $\mathrm{CH}$ & 80538 & 651 & $\begin{array}{l}\text { Transnational (www.credit- } \\
\text { suisse.com) }\end{array}$ \\
\hline & UBS & $\mathrm{CH}$ & 71076 & & Transnational (www.ubs.com) \\
\hline & $\begin{array}{l}\text { Hypo- } \\
\text { Vereinsbank }\end{array}$ & $\mathrm{D}$ & 65000 & 716 & $\begin{array}{l}\text { Transnational } \\
\text { (www.hypovereinsbank.com) }\end{array}$ \\
\hline & $\begin{array}{l}\text { Dresdner } \\
\text { Bank }\end{array}$ & $\mathrm{D}$ & 51456 & 483 & $\begin{array}{l}\text { Transnational } \\
\text { (www.dresdnerbank.com) }\end{array}$ \\
\hline & $\begin{array}{l}\text { Deutsche } \\
\text { Bank }\end{array}$ & $\mathrm{D}$ & 98311 & 940 & $\begin{array}{l}\text { Transnational } \\
\text { (www.deutschebank.com) }\end{array}$ \\
\hline & $\begin{array}{l}\text { Commerz- } \\
\text { bank }\end{array}$ & $\mathrm{D}$ & 39044 & 459 & $\begin{array}{l}\text { Transnational } \\
\text { (www.commerzbank.com) }\end{array}$ \\
\hline & $\begin{array}{l}\text { Förenings- } \\
\text { sparbanken }\end{array}$ & $S$ & 16000 & 105 & $\begin{array}{l}\text { Transnational } \\
\text { (www.foreningssparbanken. } \\
\text { com) }\end{array}$ \\
\hline
\end{tabular}

\footnotetext{
1 Volume of managed funds
} 


\section{In-depth-benchmarking}

In this part we describe the in-depth-benchmarking. We analyzed every bank in Table 1 regarding their internal processes, their credit products and their investments products.

\section{Internal processes}

In our study we could find three categories:

1. Leaders: In this group we find Triodos and the UmweltBanks as well as the Co-operative Bank.

2. Middle: Universal Banks, which implemented an environmental and social management systems and show first successes.

3. End: No or only little data about their internal environmental performance show DtA, BOS, DEG, Friends Provident, SPG (SAM) and SEB-Invest.

TRIODOS and UmweltBank do have a clearly formulated and published business strategy concerning their environmental management. They are certified and do have specialized employees who are working on this field. We rated those two banks better than the most Universal Banks, because their environmental impact per unit is lower than at other banks and because their social engagement is higher.

An employee of TRIODOS for example is using only one third of the energy of an employee of Credit Suisse Group (1977 kWh/person vs. $6600 \mathrm{kWh} /$ person). TRIODOS reaches this outstanding result by using energy saving lighting, equipment and an optimized air ventilation system instead of using air condition. In addition there are panels to show the energy use to the employees. UmweltBank and TRIODOS are producing a part of their energy by using solar panels as well. However both banks show some weakness in their paper use, which is relatively high. Though they are using only certified paper products they send out a lot of information to their stakeholders on paper.

The social performance is characterized by gender equality regarding salaries and the integration of all employees in the decision processes. TRIODOS does that by using questionnaires, employee meetings and the encouragement of bringing in own ideas and initiatives. At the UmweltBank the employees participate in the profit of the bank. In 2001 10\% of the recapitalization is reserved for employees.

Another difference between TRIODOS and the Universal Banks is the strong relation to non-governmental organizations. In doing so the bank is able to perceive societal developments early and to integrate those in their product- and service development.

Both banks are active in reducing the impact of the mobility of their employees as well. The UmweltBank pays the costs to use public transportation for their employees and provides their employees with their solar station to reload electro vehicles. TRIODOS compensates the $\mathrm{CO}_{2}$ emission by business travel by planting forests as $\mathrm{CO}_{2}$ sinks. 
Some other banks started to use standardized live cycle assessment to measure their environmental impacts using environmental eco points.

The Co-operative bank shows an outstanding performance in both social and environmental standards as well. The bank made most of their branch offices accessible for handicapped persons and offers a service of printing banking documents in Braille or bigger letters. In addition they implemented environmental and ethical standards for their suppliers and communicate those in seminars and workshops. The environmental performance of this bank is one of the best as well. Especially regarding energy use they are at the top of all banks of the sample.

The "Partnership-Report" of the Co-operative Bank awarded some prices so far as well. The bank reports about its environmental and social efforts and development and sets measurable goals, which can be tested the following year. An external auditor verifies those sustainability goals and measures as well as financial data. In addition Co-operative bank cooperates with NGO's by offering credit cards on which a specified amount of the volume flows as donation to the NGO.

The international universal banks implemented environmental and social management systems mostly using ISO 14001. While most banks divide internal and product sustainability RABOBANK integrates both in one division. The specialists of this department do not only develop new measures and products, but implement them actively as well.

A great number of universal banks of German speaking countries use the VfU²-standard or $\mathrm{EPI}^{3}$ Finance standard to measure and to report their environmental impact. Thus a comparison of the environmental impact on a high level is possible.

However there is often some discrepancy between environmental management and environmental performance. As an example none of the Swiss Banks could reach their goal to reduce their energy use. This shows that environmental management and environmental performance can correlate but must not.

All in all we can say that the alternative or environmental oriented banks integrate sustainability equal to other goals into their business policy and strategy. Sustainability becomes one main business goal. These banks want to foster sustainability by doing their business and do not only want to use sustainability if it is useful for their business.

\footnotetext{
2 Verein für Umweltmanagement in Banken, Sparkassen und Versicherungen (Association for Environmental Management in Banks, Saving Banks, and Insurances), www.vfu.de

3 Environmental Performance Indicators for the Finance Industry, www.epifinance.com
} 


\section{Credit business}

Looking back in time the credit business was the first business operation dealing with environmental risks. The famous "Fleet Factors Case" in the U.S. (Price \& O'Hare, 1993) was a kind of a starting point for banks in the U.S. and later in Europe to begin with handling environmental risks in credit business. Especially the installation of environmental laws - and here especially laws concerning soil contamination - made banks managing those risks, because in some cases the could be made responsible for a soil contamination of their debtor or they lost money because a contaminated site used as collateral lost its value. Later "positive" environmental aspects and laws influenced the creation of new credit products for special environmental or social investment, for example for building low energy houses or for micro credits.

To compensate lower returns of those loans sometimes they are connected to special saving products where savers resign a part of the interests or there are special tax reductions for some sustainable investment products, which make them interesting for investors.

Further on we will describe the "leader"products in the following business fields:

- General credit business including environmental risk management systems

- Green Funds under Dutch Law

- Loans for environmental and social projects with lower interest rates

- Environmental housing mortgage

- Public promotional loans for SME's

- Financing of wind power stations

- Micro credit Funds for developing countries

We compared 34 products in theses business fields. In every field there is some heterogeneity of the products. However we could find some very sustainable products in every field. As best category we rated the "Green Funds" and loans for environmental and social investments, because they do have a positive impact on sustainable development and not only reduce risks or increase the benefit of the banks.

All banks in the group of the leaders did integrate to some extension sustainability aspects into their credit business. Again the leaders regarding sustainability are TRIODOS and UmweltBank, which only invest in social and environmental harmless businesses, projects and sectors. Main debtors of those banks are sustainable energy production companies, organic farming, food production and trade companies, and environmental technology producers. They also finance institutions to foster SME's, cultural and educational projects, environmental friendly housing and projects in the healthcare and social sector.

Both banks do have negative criteria for all their business, which are controlled by an independent advisory council. Thus they do not sell sustainable products as special product on the on hand and invest in environmentally and socially harmful projects with their standard products like the universal banks. The UmweltBank for example does not invest in coal and 
nuclear power stations, trade and production of weapons and military goods, and trade and production of environmentally harmful products.

Both banks do quantify the environmental and social benefits of their business as well. UmweltBank quantifies the savings of $\mathrm{CO}_{2}$ emission of their alternative energy projects. In addition both banks publish the sectors in which they invest and show examples of their investments.

Since the Co-operative Bank installed an Ethical Policy in 1992 they exclude some sectors or projects out of ethical reasons. Nevertheless Co-operative Bank is not a specialized environmental or social bank.

Criteria of this bank to exclude projects or products from financing are:

- Disregard of human rights

- Production and trade of military goods

- Money laundering, drugs, and other law violations

- Trade in development countries, which are irresponsible regarding marketing practices

- Speculations

- Production and trade of tobacco

- Production and trade of fossil energy

- Production of persistent or environmentally harmful chemicals

- Non-sustainable use of natural resources

- Animal experiments for cosmetics and household products

- Conventional farming

- Production and trade of furs

It is unique how Co-operative bank is creating its Ethical Policy. They integrate their stakeholders, especially the customers in this process. They send out questionnaires in which customers have the opportunity to give their opinion about special topics like for example genetic modification. The Co-operative bank gives some explanation about the topic and the customers then can choose how this topic should be handled in the Ethical Policy.

All the other banks just integrate sustainability as environmental risks in their credit business. Only RABOBANK tries to use positive effects of sustainable action as well. They try to find out if there is a potential to improve the performance of a credit by using energy efficiency measures of reducing environmentally harmful substances and products. Thus they hope that the environmental and economical performance of an investment improves.

\section{Green Credit Funds}

A special product is the green credit fund in the Netherlands. There since 1995 exists a law that one does not have to pay capital income tax for green credit funds if at least $70 \%$ of the money is invested in green projects. At present this tax reduction makes $2.5 \%$. Thus Dutch 
people can invest their money in green funds without having less income because of lower output rates. All these special projects to which these funds give loans have to be certified by the Dutch Environmental Ministry. Especially those projects, which would not be financed under normal circumstances, become certified.

The following list shows those sections which can be tax reduced:

- Natural environment, forestry, landscape and organic farming

- forestation, development and maintaining of natural reserves and cultural goods, production and us of product of organic farming, industrial processing of non-food farming goods

- Sustainable energy

- Energy production using biomass

- Solar- and wind-energy

- Use of geothermal energy and heat pumps

- Use of water power

- Use of communal district heating and heat - power - stations for greenhouses

- Housing

- Houses built of energy saving and environmental friendly materials

- Green mortgage

- Farming

- Animal friendly farming

- Green label greenhouses

- Soil decontamination

- Bicycle lines

- Other projects

There are funds of three Dutch Banks, the ASN Green Project Fund, TRIODOS Green Fund and RABOBANK Green Interest Fund. All these funds are interest funds investing in credits for projects, which generate environmental or social benefits. Because of the tax reduction the interests of the credit are about $1 \%$ lower than without the tax reduction.

\section{Green loans with interest reduction}

We could find interest-reduced loans at TRIODOS, Zürcher Kantonalbank (ZKB) and Cooperative Bank. TRIODOS gives those loans to projects and initiatives with social or environmental goals. ZKB gives interest-reduced loans for houses, which outperform environmental standards and for SME's. Co-operative banks gives those loans to companies from the environmental sector.

While Co-operative bank gives these $0.5 \%$ reduced loans only to commercial debtors, ZKB and TRIODOS gives them to private debtors as well. Thus those loans are combined with special 
savings accounts with reduced interests but guarantees that this money will only be used for sustainable credits. TRIODOS UK has some special "theme-accounts" like Organic Saver Account or Earth Saver Account where the money flows only in defined sectors.

The difference between TRIODOS and the others is that they combine environmental and social benefits while ZKB and Co-operative only offer credits for environmentally friendly projects.

In cooperation with the Quaker-foundation Co-operative bank offers a special housing mortgage for socially unprivileged groups as well.

\section{Environmentally friendly mortgages}

There are three environmental mortgage products that we could identify as sustainable. There is the Umweltbaufinanzierung (environmental construction financing) of the UmweltBank, green mortgages of the TRIODOS and the ImmoPass (real estate certificate) of the HypoVereinsbank.

The UmweltBank connects the environmental performance of the house with the interest rate. The more point the debtors gets on a checklist the less interest he hast to pay. All in all they give a reduction of .45 percentage points. In addition the reduction of the environmental impact is part of the product environmental balance of the bank.

The Co-operative bank donates money to climate protection projects. Thus they reduce $25 \%$ of the $\mathrm{CO} 2$ emission of one household. In addition they offer advices on energy efficiency of houses.

The Immopass of the HypoVereinsbank is not a credit product in the narrow sense, but a certificate that guarantees good construction quality, healthy and energy-efficient construction. The certificate can be used at a sale of the house or for the proposal for a mortgage.

\section{Environmental loans of public banks}

There is a wide range of environmental loans given by public banks. Non-public banks arrange most of these loans. One exception are the loans of the polish BOS. The interest rates of these loans are normally lower than standard products, but are connected to a checklist. On the other hand the criteria are not that detailed than those of some non-public banks especially according to the sectors.

We analyzed products of the polish BOS, the European Investments Fund and the Deutsche Ausgleichsbank (DtA) in Germany.

The leader of those three is BOS, especially because they publish the environmental benefit of their loans on a yearly basis. They publish regional dust, $\mathrm{SO}_{2}$, and $\mathrm{NO}_{x}$ reductions, the volume of sewage of financed sewage plants, capacity of waste of financed waste sites and the length of financed sewers. 


\section{Micro Credit Funds}

There are two Dutch banks, TRIODOS and ASN, which offer micro credit funds. Both are connected to a special savings account with standard interest rates. In addition the customer can donate a part of the interest earnings to development projects. In the case of the TRIODOS Hivos fund, Hivos, a NGO development organization, takes 905 of the failure risk for the given credits. The saver takes only $10 \%$ of the risk, which in case he can be declare as a donation.

\section{Asset management}

We evaluated 48 products of 17 banks. We categorized the products in five groups:

- Equity funds

- Mixed equity and bond funds

- Bond funds

- Sector specific investment companies and funds

- Sector specific basket certificates and index certificates

\section{Equity funds}

We analyzed 24 equity funds of 13 banks, which are investing in shares using ethical, environmental or sustainable criteria. As leaders we identified SWISSCA Green Invest by the Zürcher Kantonalbank (ZKB) and the Venture Capital Fund by TRIODOS. These funds evaluate both environmental and social criteria.

Most of these funds exclude sectors working in the field of pesticides, tobacco, gambling, weapon, military equipment, and drugs of all kind. SWISSCA Green Invest excludes additionally sectors working in the field of production and trading of non-renewable energy sources, automobile and aircraft industry, and airlines. In addition they continuously monitor company policies and practices. Mass dismissal, disregard of human rights, and other ethically critical operations can lead to an exclusion of a company. We found similar criteria only for the TRODOS funds.

TRIODOS used a more positively driven approach, while investing in sectors, which are defined sustainable. Those are production and trade with organically farmed products, production and trade with renewable-energy, sustainable mobility like mass transport or bicycles, healthcare, sustainable financial service providers, environmental technology and consultancy, education, and telecommunication.

In addition the TRIODOS Venture Capital Fund invests only in sustainable start up companies.

All in all we can say that best-in-class funds investing in sector leaders do have a lower sustainability rating than funds excluding sectors because of sustainability reasons. 


\section{Mixed Funds}

Mixed funds are investing in both equity and bonds. There are two mixed funds being valuated positively: Sarasin Fairinvest and TRIODOS Meerwarde Fund Mixed.Sarasin invest 20\% in pioneer companies and has detailed criteria to valuate the sustainability of governmental bonds. To judge the sustainability of states they use the criteria presented in Table 2.

\begin{tabular}{ll}
\hline Environmental Aspects & Social Aspects \\
\hline Energy use (i.e. per GNP and person) & Debts \\
Soil consumption and soil contamination & Human rights \\
Water consumptions & Education \\
Air pollution & Health \\
Biodiversity & Income \\
\hline
\end{tabular}

Table 2: Criteria to judge the sustainability of states

TRIODOS Meerwarde does not invest in the alcohol, tobacco, gambling, weapon, nuclear, and porn industry and in non-sustainable fishing, car, airline, oil, and gas industry and in big water power stations.

They prefer to invest in renewable energy, sustainable mobility, tourism, banking, health, and education and telecommunication industry. In addition they prefer governmental bonds of countries handling environmental and societal problems in a progressive way. They do not invest in countries accepting or fostering corruption, dictatorship, violation of human rights or discrimination of minorities.

\section{Industry specific and funds in renewable energies}

There are three investment companies called New Energy Invest AG of Sarasin Bank, Prime New Energy of CSC and Smart Energy of SAM. In addition we analyzed the Future Energy Fund, Windpark Fund, and New Power.

The investment companies invest in SME's producing wind or solar energy, building parts like fuel cells or offer services in the field of renewable energy. All invest in sector leaders and in private equity. The three investment companies are quite new on the market and are similar.

The funds are investing in similar industries. But both are more directly performance oriented and sustainability aspects are not primary. Both fund do not provide very good information.

\section{Sustainability in investment banking}

In contrast to other banking fields are sustainability aspects in investments banking very few. Thus we only can give a short spotlight on this topic. International banks perform environmental impacts assessments for project they are investing in. Goal is the compatibility to the guidelines of international organizations like the UNO (UUN Global Compact Initiative) or the Worldbank and the national regulations respectively. Some investment banks implemented own sustainability guidelines, which analyze environmental and social risks of investment projects. 
Some NGO's tried to work out guidelines for investment banking. The Friend of the Earth Guidelines do demand that

- The project development is transparent, participative and open for all stakeholders

- All information is transparent

- All the development opportunities of the region, inclusive the "no project solution" have to be analyzed

- All influences and risks should be analyzed and published

- Local communities have to get working opportunities

- The project should foster local micro credits and should have an impact on the local economy

- The educational level of the population should be improved

- Poorer people should have benefits

- Human rights and needs of the local population should be respected

- Environmental standards and environmental measures should be improved

- Natural spaces should be conserved and saved

- The consummation of non renewable resources should be decreased and the use of renewable resources should be fostered

- International agreements should be respected (Friends of the Earth, 2001).

\section{Models of integrating sustainability in to the banking business}

Out of the analysis and in depth interviews in banks we could extract five models of integrating sustainability into the banking strategy. These models can be used to analyze the motives of banks to integrate sustainability into their strategies and to understand the risks and opportunities to use sustainability in the banking sector. These models are:

- Event related sustainability integration

- Sustainability as a new banking strategy

- Sustainability as value driver

- Sustainability as a public mission

- Sustainability as requirements of clients

\section{Event related sustainability integration}

What happened in a city where chemical industry and private banking are the most important economic industries? In addition it is a city, which is not too big so that the representatives of the industry know each other and are emotionally tied to this city. Once in this city there was the biggest accident in the chemical industry in the country. Millions of liters of a mixture of water and chemical flew in the biggest European river. But there was no chance to 
stop this catastrophe fast and everybody living in the city could watch the consequences personally or read the news in the newspapers or could watch them in TV.

At this time the representatives of a well-known Swiss Private Bank talked to each other and were quite concerned about this accident. In addition some client asked the bank if they do have a kind of "environmental asset products". Thus they asked themselves if there is an opportunity for a bank to do something for the environment what maybe could prevent such accidents. But they could not find an easy answer on that question. Thus they started to create an environmental techniques fund. But out of many reasons this product was not very successful. Thus as a next step they created a fund which contents the most eco-efficient companies in 1994. In contrast to the first this product was economically very successful and built a basis to create similar product basing on a deep analysis of environmental and social performance of the companies the funds are investing in.

This is the example of Bank Sarasin with their environmentally and socially sound investment product, which brought the bank into the perception of many people interested in this topic. The starting point was a personal concern of the leaders, which were not highly interested in environmental concern before the accident. They also did not know from the start how to create an environmental financial product. But the personal concern made this project running an gave it support from the leaders of the bank.

Such events are they negative or positive can be a starting point to integrate sustainability aspects in the business policy and strategy. Positive events could be the introduction of an environmental tax or a worldwide conference on sustainability. However one important condition is that the leaders of a bank foster the integration because normally the competences are not available in the organization.

One more conditions of success in this case was the good financial performance of the eco-products, which make them competitive to other "non-environmental" financial product.

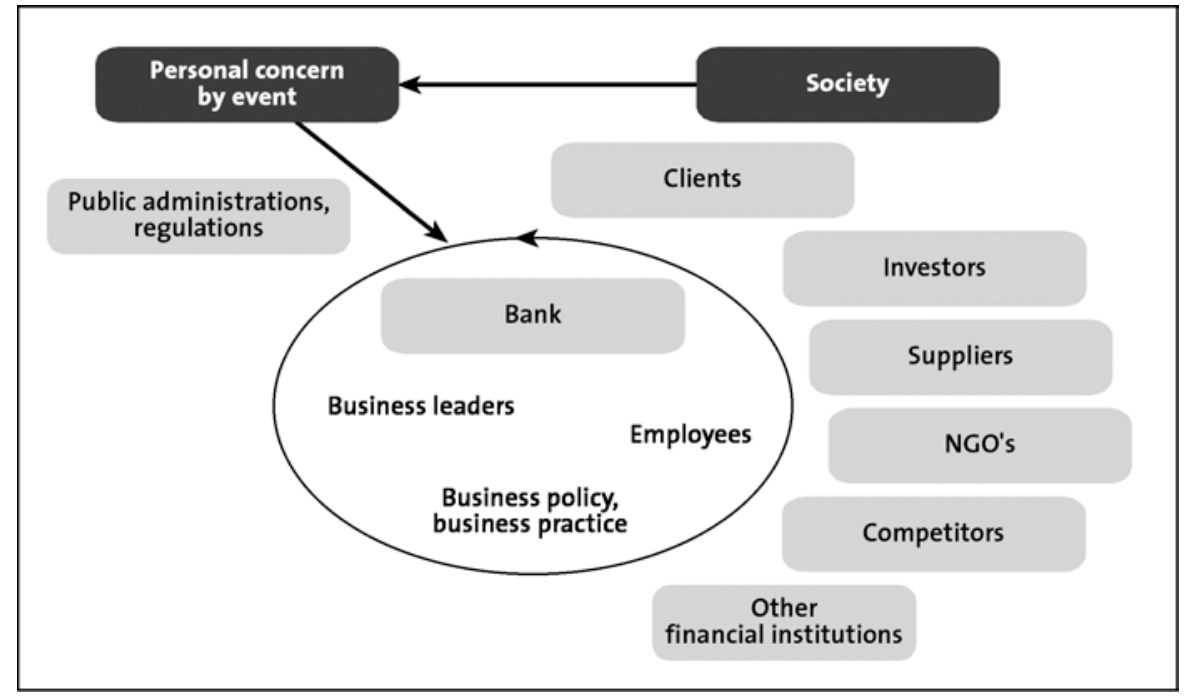

Figure 2: Event related sustainability integration 


\section{Sustainability as a new banking strategy}

What happens if a group of experts with a anthroposophist background try and find how money can be handled consciously? This happened 1968 in the Netherlands and lead to the foundation of TRIODOS Bank in 1980. This bank only does sustainable business which means it includes social and ethical - as well as financial - perspectives in its business mission, strategy and practices. Thus they tried to use a new principle in banking which is leading the whole business of the bank. The basis is to handle money consciously, which is different from most other banks in the world.

Thus TRIODOS is a good example how sustainability can be integrated into the whole banking business and to influence the whole financial sector.

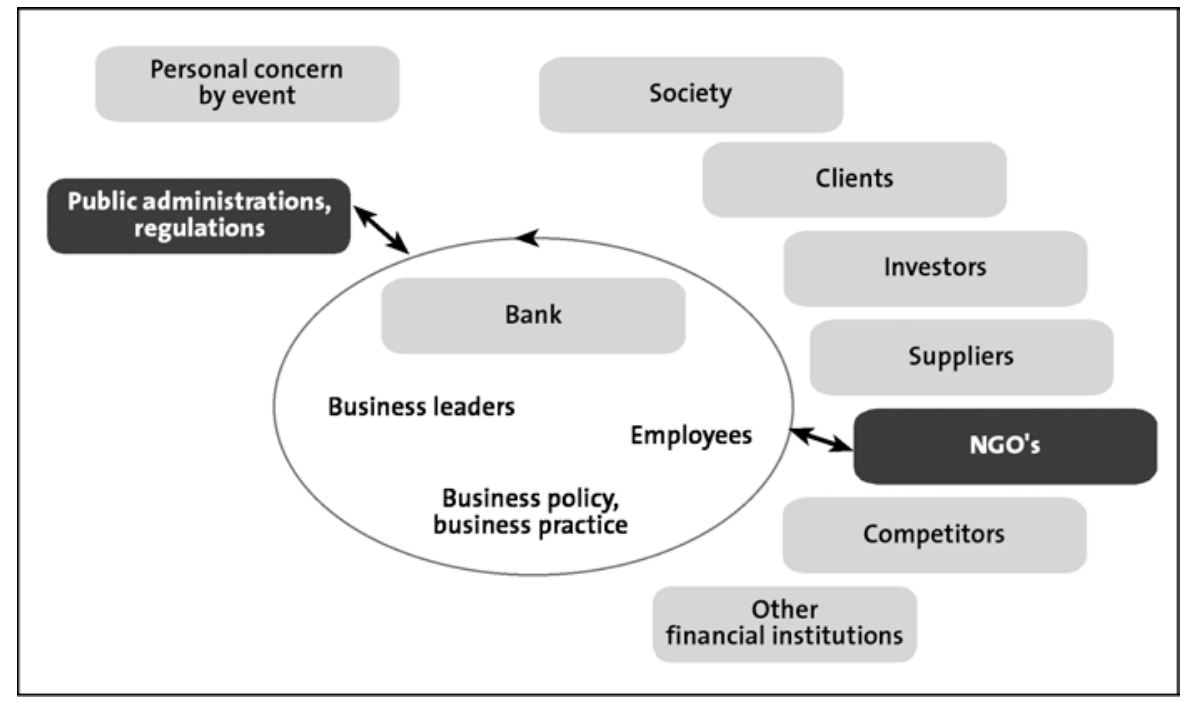

Figure 3: Sustainability as a new banking strategy

\section{Sustainability as a value driver}

Why did the concept of sustainability spread from very specialized financial institutions to the global acting transnational banks as well?

Beginning with managing environmental risks in credit management in the early 9os, banks found that environment and sustainability are not only business risk, but business opportunities as well. Thus they started to create sustainable asset product, eco-mortgages and other similar products. The difference to the concept of sustainability as a new banking strategy that those products and services are normally not in the core of the business and do not play a big role monetarily. However the products and services are well perceived in the public and could help to create a better image for those banks. The strategy is to use the concept of sustainability if it is a value driver and has a positive impact economically and for the image of the bank. But those products are standing between all the other products and services, which not all can be valued as sustainable. The business strategy itself is not influenced by the concept very much as well. 


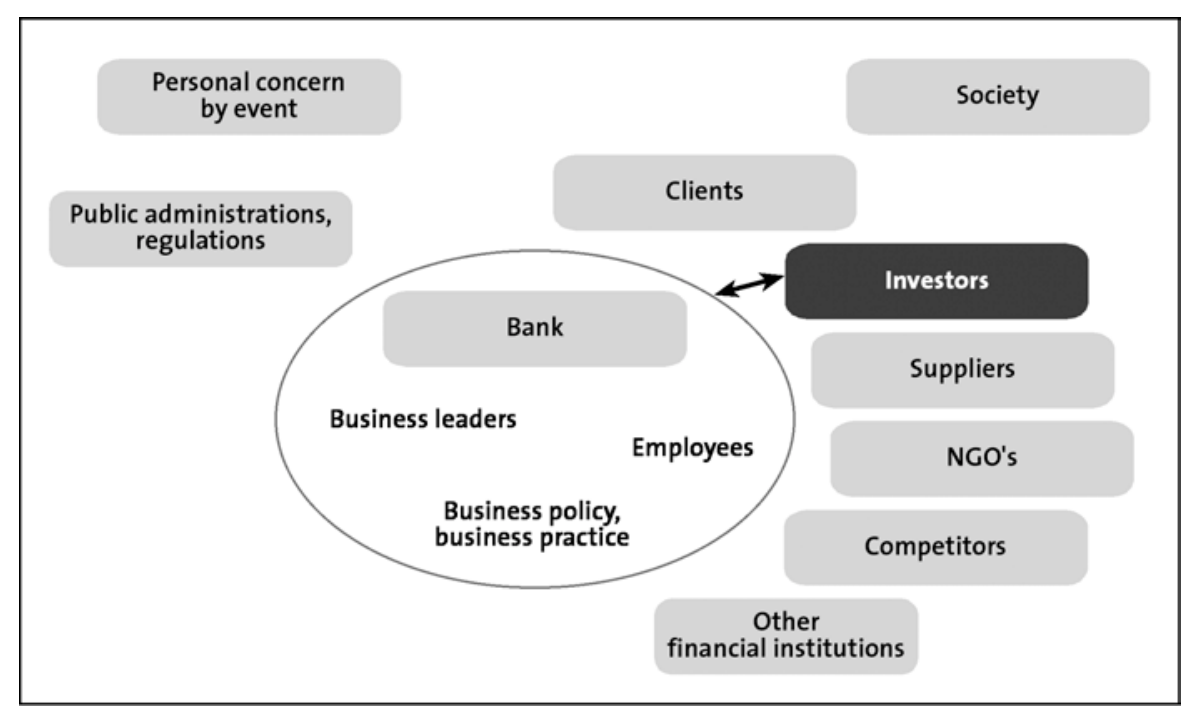

Figure 4: Sustainability as value driver

\section{Sustainability as public mission}

Some banks do have public responsible bodies. Officially those banks perform their business on behalf of a public body like a state, canton or a local authority. However sometimes those authorities do have a sustainability mission. Then the banks normally integrate this mission into their own mission as well. As an example the mission of the Zurich Cantonal Bank contents the task to contribute to the sustainable development of the Canton of Zurich. There are similar constellations in other countries as well. Thus the public opinion influenced the strategy of the bank via Cantonal Administration. In the case of the ZKB the bank did bring the sustainability mission into practice and created sustainable products and services like funds and environmental loans and mortgages and engages in public project regarding the sustainable development in the Canton of Zurich.

However the connection to the public administration must not have a positive impact on the operative business. Inside the bank there must be a willingness to use the mission and actively create sustainable products and services.

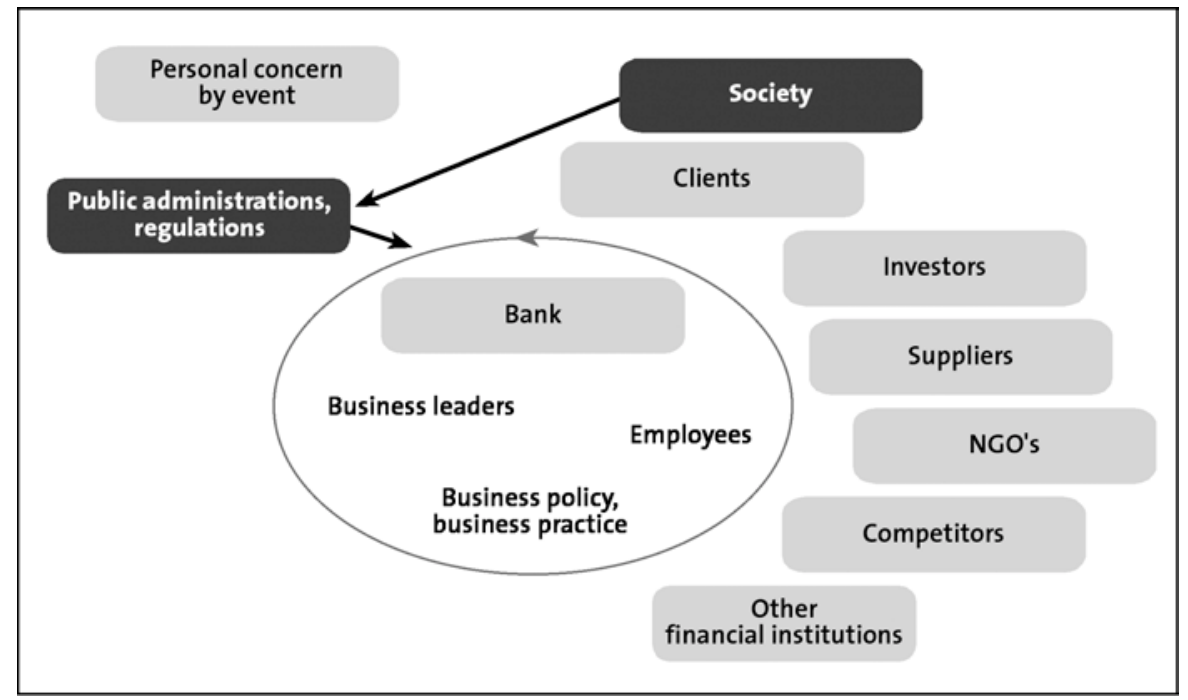

Figure 5: Sustainability as public mission 


\section{Sustainability as a requirement of clients}

What is the image of a bank from the clients' point of view? The regional Co-operative bank carried out a survey in 1988 where they asked their clients about the image of the bank. It was a bit surprisingly for the representatives of the bank that their clients perceived the bank as socially responsible. Thus the bank started to use this image and to create socially responsible business to differentiate from their competitors. Thus in 1992 the bank developed an ethical policy. The bank adapts the criteria of this policy to the wishes and the needs of the clients regularly.

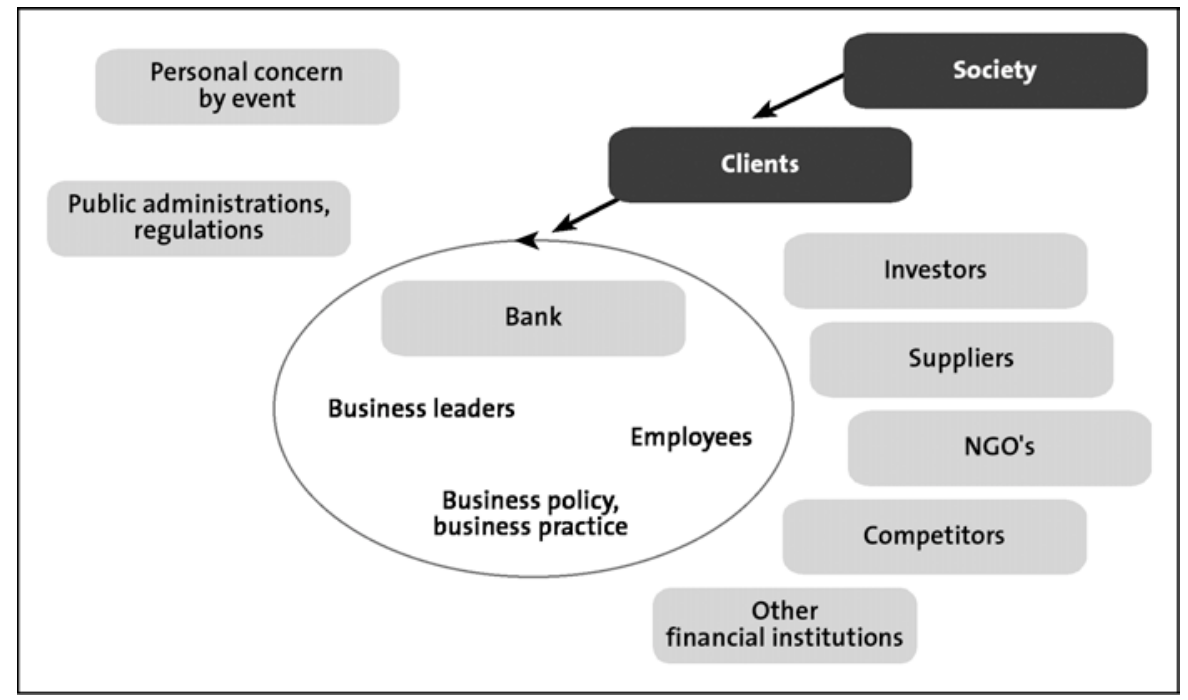

Figure 6: Sustainability as a requirement of clients

However it is hard to prove that this ethical brand is contributing something to the profit of the bank Co-operative Banks reports that the ethical Brand is contributing between $15 \%$ and $18 \%$ to the profit. In addition the Bank is one good example to perform classical, universal banking business without violating criteria of sustainable development and in addition creates products with a positive impact on sustainability. In the last eight years the banks performed economically much better than the average of British banks.

\section{Strategies to implement sustainability into the banking business}

After presenting some models of sustainable banking we now want to show how these models can be integrated into the banking business. Looking on the benchmarking analysis it becomes clear that the integration of sustainability into the banking business is successful:

- if the leaders of the bank are supporting the integration (top-down process) and

- if it is implemented into operative business on the level of products, services and processes. 
All sustainability leaders used both approaches simultaneously. Thus to use this approach there are different complementary strategies:

- Implementation by a pilot group

- Changing of the business strategy of the bank

- Problem-oriented strategy and

- Shifting of responsibility and competences for sustainability from staff to line management.

\section{Implementation by a pilot group}

A pilot group starts with a new sustainable product. Is there a success to see it can be analyzed which were the reasons for success and the bank can try to generalize these aspects to other new products.

The advantage of this strategy is to minimize the risk of failure to a small part of the bank. In addition the reasons of failure can be analyzed as well.

\section{Changing of the business strategy of the bank}

We could not find an example for a radical changing of the business strategy in our benchmarking study. However it is possible in case of the foundation of a new bank or in case of changing the structure, maybe in the case of privatizing. A sustainable banking strategy does not mean to stop the standard banking business, but can mean to have a sustainability guideline for all the products and services of a bank like Co-operative Bank does.

\section{Problem oriented strategy}

This strategy tries to solve the present problems of a bank by using a holistic strategy instead of solving single problems. Sustainability can be such a holistic strategy. In the case of public banks and the pressure of privatizing those banks, sustainability can compensate the public mission.

\section{Shifting of responsibility and competences for sustainability from staff to line man- agement}

Often sustainability and environmental management takes place in the staff. In the phase of initiating broader concepts into a bank this strategy is very useful.

The disadvantage of such a strategy is that normally the staff does not have very intensive relations to the line management, which is responsible for products, services and processes. Thus it is useful to change the implementation of sustainable products, services and processes from staff to line management to connect the development and the implementation of a sustainable product or service.

One good example is the Dutch RABOBANK, which has responsible line managers for sustainability in every business unit. They can foster the implementation of sustainable products and services from their operative point of view. 


\section{Principles of sustainable banking}

We want to finish by showing three principles of integrating sustainability into banking policy, strategy and operative business, which can lead to sustainable banking:

- Principle 1: integration of sustainability into the core business of banks

The benchmarking shows that leading banks regard sustainability not only as task in connection to charity actions or corporate citizenship, but they use the concept value driven. That means they are convinced that the integration of sustainability aspects contributes to a business advantage in their products, processes and services.

- Principle 2: integration of sustainability into the general business strategy of a bank

Sustainable management belongs to the general strategy of the leading sustainable banks. It influences the goals of the bank and is not only part of an environmental or social strategy. This does not mean a change from a universal to an eco-bank. But sustainability is on criteria in all business aspects of a bank.

- Principle 3: Sustainability is not a soft factor, but a measurable business result

Leader banks measure their performance in sustainability and communicate the results. Thus they can proof the success of their sustainable products, services, and processes.

To do so it is necessary to develop indicators for sustainable behavior in banks. Those indicators must be on the one hand comparable between banks and on the other hand that specific to measure the performance of a single bank.

\section{References}

Friends of the Earth. (2001). Friends of the Earth Development Screen.: Friends of the Earth.

Jeucken, M. (2001). Sustainable finance and banking: the financial sector and the future of the planet. London: Earthscan Publications.

Mertins, K., Siebert, G., \& Kempf, S. (Eds.). (1995). Benchmarking. Praxis in deutschen Unternehmen. Berlin: Springer.

Price, C., \& O’Hare, R. (1993). Rise of environmental due diligence. BNA's environmental due diligence guide(101), 301-311.

Schmidheiny, S., \& Zorraquin, F. (1996). Financing change: the financial community, eco-efficiency, and sustainable development. Cambridge, MA: MIT Press.

UNEP. (1992). Statement by Banks on the Environment and Sustainable Development. Rio de Janeiro: United Nations Environmental Program. 
- UNS-Working Paper 1 (Out of Print) Scholz, R.W. (1994). Muss man den Formalismus beherrschen, um die Formalisten zu schlagen? Zürich: ETH Zürich, Umweltnatur- und Umwelt sozialwissenschaften.

(Published as: Scholz, R.W. (1998). Umweltforschung zwischen Formalwissenschaft und Verständnis: Muss man den Formalismus beherrschen, um die Formalisten zu schlagen? [Environmental research between formal science and comprehension: is command of the formalism necessary for sion: is command of the formalism necessary for Schröder (Eds.), Umweltforschung quergedacht: Perspektiven integrativer Umweltforschung und lehre [Environmental research thought laterally: perspectives on integrating environmental research and teaching] (pp. 309-328). Berlin: Springer.)

UNS-Working Paper 2 (Out of Print)

UNS (1994). Lehrstuhlbeschreibung Umweltnaturund Umweltsozialwissenschaften (UNS). Fallstudie, Forschung und Berufspraxis. Zürich: ETH Zürich, Umweltnatur- und Umweltsozialwissenschaften.

UNS-Working Paper 3

Mieg, H.A. (1994). Die Expertenrolle. Zürich: ETH Zürich, Umweltnatur- und Umweltsozialwissenschaften.

- UNS-Working Paper 4

Heitzer, A. \& Scholz, R.W. (1994). Monitoring and evaluating the efficacy of bioremediation - a conceptual framework. Zürich: ETH Zürich, Umweltnatur- und Umweltsozialwissenschaften.
UNS-Working Paper 5 (Out of Print)

Scholz, R.W., Weber, O. \& Michalik, G. (1995). Ökologische Risiken im Firmenkreditgeschäft. Zürich ETH-Zürich, Umweltnatur- und Umweltsozialwissenschaften.

(Published as: Scholz, R.W., Weber, O., and Michalik, G. (1995). Ökologische Risiken im Firmenkreditgeschäft. [Ecological risks in loans to enterprises] In Overlack-Kosel, D., Scholz, R.W., Erichsen, S Schmitz, K. W., and Urban, G. (Eds.), Kreditrisiken aus Umweltrisiken [Loan risks due to environmental risks (pp. 1-49). Bonn: Economica.)

UNS-Working Paper 6 (Out of Print)

Scholz, R.W., Heitzer, A., May, T., Nothbaum, N Stünzi, J. \& Tietje, O. (1995). Datenqualität und Risikoanalysen - Das Risikohandlungsmodell zur Altlastenbearbeitung. Zürich: ETH Zürich, Umweltnatur- und Umweltsozialwissenschaften.

(Published as: Scholz, R.W., Heitzer, A., May, T. W. Nothbaum, N. Stünzi, J., and Tietje, O. (1996). Datenqualität und Risikoanalysen: Das Risikohandlungs modell zur Altlastenbearbeitung. [Data quality and risk analyses. The Risk Action Model of soil remediation] In S. Schulte-Hostede, R. Freitag, A. Kettrup, and W. Fresenius (Eds.), Altlasten-Bewertung Datenanalyse und Gefahrenbewertung [Evaluation of soil remediation cases: analysis of data and evaluation of risks] (pp. 1-29). Landsberg: Ecomed.)

UNS-Working Paper 7 (Out of Print)

Scholz, R.W., Mieg, A.H. \& Weber, O. (1995). Mastering the complexity of environmental problem solving by case study approach. Zürich: ETH Zürich, Umweltnatur- und Umweltsozialwissenschaften.
(Published as: Scholz, R.W., Mieg, H.A., and Weber, O. (1997). Mastering the complexity of environmental problem solving with the case study ap proach. Psychologische Beiträge, [Contributions to Psychology] 39, 169-186.)

- UNS-Working Paper 8 (Out of Print)

Tietje, O. \& Scholz, R.W. (1995). Wahrscheinlichkeitskonzepte und Umweltsysteme. Zürich: ETH Zürich, Umweltnatur- und Umweltsozialwissenschaften.

(Published as: Tietje, O. and Scholz, R.W. (1996). Wahrscheinlichkeitskonzepte und Umweltsysteme. [Concepts of probability and environmental systems] In A. Gheorghe \& H. Seiler (Eds.), Was ist Wahrscheinlichkeit? Die Bedeutung der Wahrscheinlichkeit beim Umgang mit technischen Risi ken [What is probability? The meaning of probability in the case of technical risks] (pp. 31-49). Zürich: vdf.)

UNS-Working Paper 9 (Out of Print)

Scholz, R.W. (1995). Grenzwert und Risiko: Probleme der Wahrnehmung und des Handelns. Zürich: ETH Zürich, Umweltnatur- und UmweltsozialwissenZürich, U
schaften.

(Published as: Scholz, R.W. (1996) Grenzwerte und Risiko: Probleme der Wahrnehmung und des Handelns. [Standards and risks: Problems of cognition and of action] In A. Grohmann \& G. Reinicke (Eds.) Transparenz und Akzeptanz von Grenzwerten am Beispiel des Trinkwassers [Transparency in the setting of standards and their acceptance in the case of drinking water] (pp. 5-19). Berlin: Erich Schmidt verlag.) 
- UNS-Working Paper 10 (Out of Print)

Weber, O. (1995). Vom kognitiven Ungetüm bis zur Unverständlichkeit: Zwei Beispiele für Schwierig keiten im Umgang mit Grenzwerten. Zürich: ETH Zürich, Umweltnatur- und Umweltsozialwissenschaften.

(Published as: Weber, O. (1996). Vom kognitiven Ungetüm bis zur Unverständlichkeit: zwei Beispiele für Schwierigkeiten im Umgang mit Grenzwerten. [From cognitive monsters to incomprehensibility: two examples of difficulties in managing stan dards] In Umweltbundesamt (Ed.), Transparenz und Akzeptanz von Grenzwerten am Beispiel des Trinkwassers. Berichtsband zur Tagung vom 10. und 11 . Oktober 1995 (mit Ergänzungen), [Transparency in and acceptance of standards. The case of drinkin water] (pp. 133-150). Berlin: Erich Schmidt Verlag.)

UNS-Working Paper 11

Oberle, B.M., Meyer, S. B. \& Gessler, R.D. (1995) Übungsfälle 1994: Ökologie als Bestandteil von Unternehmens- strategien am Beispiel der Swissair. Zürich: ETH Zürich, Umweltnatur- und Umweltsozialwissenschaften.

\section{- UNS-Working Paper 12 (Out of Print)}

Mieg, H.A. (1996). Managing the Interfaces between Science, Industry, and Society. Zürich: ETH Zürich, Umweltnatur- und Umweltsozialwissenschaften. (Published as: Mieg, H.A. (1996). Managing the interfaces between science, industry, and society. In: UNESCO (Ed.), World Congress of Engineering Educators and Industry Leaders (Vol. I, pp. 529-533). Paris: UNESCO.)

- UNS-Working Paper 13 (Out of Print)

Scholz, R.W. (1996). Effektivität, Effizienz und Verhältnismässigkeit als Kriterien der Altlastenbearbeitung. Zürich: ETH Zürich, Umweltnatur- und Umweltsozialwissenschaften

(Published as: Scholz, R.W. (1996). Effektivität, Effizienz und Verhältnismässigkeit als Kriterien de Altlastenbearbeitung. [Efficacy, efficiency and appropriateness as criteria for evaluating soil remediation cases] In. Baudirektion des Kantons Zürich in Zusammenarbeit mit ETH-UNS (Eds.) Zürich in Zusammenarbeit mit ETH-UNS (Eds.)
Grundsätze, Modelle und Praxis der AltlastenbearGrundsätze, Modelle und Praxis der Altlastenbear-
beitung im Kanton Zürich: Referate zur Altlastentagung 1996 [Principles, models and the administrative practice of soil remediation in the Canton of Zurich] (pp. 1-22) Zürich: AGW Hauptabteilung Abfallwirtschaft und Betriebe.)

\section{- UNS-Working Paper 14 (Out of Print)}

Tietje, O., Scholz, R.W., Heitzer, A. \& Weber, O. (1996). Mathematical evaluation criteria. Zürich ETH Zürich, Umweltnatur- und Umweltsozialwis senschaften.

(Published as: Tietje, O., Scholz, R.W., Heitzer, A., and Weber, O. (1998). Mathematical evaluation criteria. In H.-P. Blume, H. Eger, E. Fleischhauer, A. Hebel, C. Reij, \& G. Steiner (Eds.), Towards sustainable land use (pp. 53-61). Reiskirchen: Catena.)

\section{- UNS-Working Paper 15}

Steiner, R. (1997). Evaluationsbericht: Bewertung der obligatorischen Berufspraxis im Studiengang Umweltnaturwissenschaften durch Betriebe und Studierende. Zürich: ETH Zürich, Umweltnatur- und Studierende. Zürich: ETH Zürich,
Umweltsozialwissenschaften.

UNS-Working Paper 16 (Out of Print) Jungbluth, N. (1997). Life-cycle-assessment for stoves and ovens. Zürich: ETH Zürich, Umweltnaturund Umweltsozialwissenschaften.

(Published as: Jungbluth, N. (1997). Life-Cycle-Assessment for stoves and ovens. 5th SETAC-Europe LCAS Case Studies Symposium, (pp. 121-130), Brussels.)

\section{- UNS-Working Paper 17}

Tietje, O., Scholz, R.W., Schaerli, M.A., Heitzer, A. \& Hesske, S. (1997). Mathematische Bewertung von Risiken durch Schwermetalle im Boden: Zusammenfassung des gleichnamigen Posters auf der Tagung der Deutschen Bodenkundlichen Gesell-
schaft in Konstanz. Zürich: ETH Zürich, Umweltschaft in Konstanz. Zürich: ETH Zürich,
natur- und Umweltsozialwissenschaften.

UNS-Working Paper 18

Jungbluth, N. (1998). Ökologische Beurteilung de Bedürfnisfeldes Ernährung: Arbeitsgruppen, Me thoden, Stand der Forschung, Folgerungen. Zürich: ETH Zürich, Umweltnatur- und Umweltsozialwissenschaften.

- UNS-Working Paper 19 (Out of Print)

Weber, O., Scholz, R.W., Bühlmann, R. \& Grasmück D. (1999). Risk Perception of Heavy Metal Soil Contamination and Attitudes to Decontamination Strategies. Zürich: ETH Zürich, Umweltnatur- und Umweltsozialwissenschaften.

(Published as: Weber, O., Scholz, R.W., Bühlmann, R. \& Grasmück, D. (2001). Risk Perception of Heavy Metal Soil Contamination and Attitudes to Decontamination Strategies. Risk Analysis, Vol. 21, Issue 5, pp. 967 - 967.)

\section{- UNS-Working Paper 20}

Mieg, H.A. (1999). Expert Roles and Collective Reasoning in ETH-UNS Case Studies. Zürich: ETH Zürich, Umweltnatur- und Umweltsozialwissenschaften.

UNS-Working Paper 21

Scholz, R.W. (1999). "Mutual Learning" und Probabilistischer Funktionalismus - Was Hochschule und Gesellschaft von einander und von Egon Brunswik lernen können Zürich. ETH Zürich, Umweltnaturund Umweltsozialwissenschaften.

UNS-Working Paper 22 (Out of Print)

Semadeni M. (1999). Moving from Risk to Action: A conceptual risk handling model. Zürich: ETH Zürich, Umweltnatur- und Umweltsozialwissenschaften.

(Published as: Semadeni, M. (2000). Moving from risk to action: A conceptual risk handling model. In R. Häberli, R. Scholz, A. Bill, \& M. Welti (Eds.), Proceedings of the International Transdisciplinarity 2000 Conference: Transdisiplinarity - Joint Problem-Solving among Science, Technology and Society. ETH Zurich. Workbook I: Dialogue Sessions and Idea Market (pp. 239-234). Zürich: Haffmanns Sachbuch Verlag.)

\section{- UNS-Working Paper 23 (Out of Print)}

Güldenzoph, W., Scholz, R.W. (2000). Umgang mit Altlasten während dem Transformationsprozess im Areal Zentrum Zürich Nord (ZZN). Zürich: ETH Zürich, Umweltnatur- und Umweltsozialwissenschaften

(Published as: Güldenzoph, W., Baracchi, C., Fagetti, R., \& Scholz, R.W. (2000). Chancen und Dilemmata des Industriebrachenrecyclings: Fallbetrachtung Zentrum Zürich Nord [Opportunities and dilemmas in the recycling of industrial "brownfields": Case study city center Zurich North]. DISP 143 [Documents and Information on Local, Regional, and Country Planning in Switzerland], 36, 10-17.)

UNS-Working Paper 24

Semadeni M. (2000). Soil and Sustainable LandUse. Zürich: ETH Zürich, Umweltnatur- und Umweltsozialwissenschaften

ש UNS-Working Paper 25

Sell J., Weber, O., Scholz, R.W. (2001). Liegenschaftsschatzungen und Bodenbelastungen. Zürich: ETH Zürich, Umweltnatur- und Umweltsozialwissenschaften
- UNS-Working Paper 26 (Out of Print)

Hansmann, R., Hesske, S., Tietje, O., Scholz, R.W (2001). Internet-unterstützte Umweltbildung: Eine experimentelle Studie zur Anwendung des OnlineSimulationsspiels SimUlme im Schulunterricht Zürich: ETH Zürich, Umweltnatur- und Umweltsozialwissenschaften.

(Published as: Hansmann, R., Hesske, S., Tietje, O. Scholz, R.W. (2002). Internet-unterstützte Umweltbildung: Eine experimentelle Studie zur Anwendung des Online-Simulationsspiels SimUlme im Schulunterricht. Schweizerische Zeitschrift für Bildungswissenschaften, Nr. 1/2002.)

- UNS-Working Paper 27

Scholz, R.W., and Weber, O. (2001). Judgments on Health Hazards to Soil Contamination by Exposed and Not-exposed Residents. Zürich: ETH Zürich, Umweltnatur- und Umweltsozialwissenschaften.

- UNS-Working Paper 28

Scholz, R.W., Steiner, R. and Hansmann, R. (2001). Practical Training as Part of Higher Environmental Education. Zürich: ETH Zürich, Umweltnatur- und Umweltsozialwissenschaften.

UNS-Working Paper 29

Hansmann, R., Scholz, R.W., Crott, H.W., and Mieg, H.A. (2001). Education in Environmental Planning Effects of Group Discussions, Expert Information, and Case Study Participation on Judgment Accuracy. Zürich: ETH Zürich, Umweltnatur- und Umweltsozialwissenschaften.

UNS-Working Paper 30

Laws, D., Scholz, R.W., Shiroyama, H., Susskind, L., Suzuki, T., and Weber, O. (2002). Expert Views on Sustainability and Technology Implementation. Zürich: ETH Zürich, Umweltnatur- und Umweltsozialwissenschaften.

UNS-Working Paper 31

Flüeler, T. (2002). Robust Radioactive Waste Management: Decision Making in Complex Socio-technical Systems. Part1 = Options in Radioactive Waste nical Systems. Part1 = Options in Radioactive Waste Management Revisited: A Proposed Framework for
Robust Decision Making; Part $2=$ Robustness in Robust Decision Making; Part 2 = Robustness in
Radioactive Waste Management. A Contribution to Decision Making in Complex Socio-technical Systems. Zürich: ETH Zürich, Umweltnatur- und Umweltsozialwissenschaften

(Part 1 published as: Flüeler, T. (2001a): Options in Radioactive Waste Management Revisited: A Framework for Robust Decision Making. Journal of Risk Analysis. Vol. 21. No. 4. Aug. 2001:787-799.

Part 2 published as: Flüeler, T. (2001b): Robustness in Radioactive Waste Management. A Contribution to Decision-Making in Complex Socio-technical Systems. In: E. Zio, M. Demichela \& N. Piccinini (eds.): Safety \& Reliability. Towards a Safer World. Proceedings of the European Conference on Safety and Reliability. ESREL 2001. Torino (I), 16-20 Sep. Vol. 1. Politecnico di Torino, Torino, Italy:317-325.)

\section{- UNS-Working Paper 32}

Hansmann, R., Mieg, H.A., Crott, H.W., and Scholz, R.W. (2002). Models in Environmental Planning Selection of Impact Variables and Estimation of Impacts. Zürich: ETH Zürich, Umweltnatur- und Umweltsozialwissenschaften.

- UNS-Working Paper 33

Schnabel, U., Tietje, O., and Scholz, R.W. (2002). Using the Power of Information of Sparse Data for Soil Improvement Management. Zürich: ETH Zürich, Umweltnatur- und Umweltsozialwissenschaften.

- UNS-Working Paper 34

Weber, O., Reiland, R., and Weber, B. (2002). Sustainability Benchmarking of European Banks and Financial Service Organizations . Zürich: ETH Zürich, Umweltnatur- und UmweltsozialwissenZürich,
schaften. 